\title{
WOOD RESEARCH
}

\section{6(2): 2021}

Wood Research publishes original papers aimed at recent advances in all branches of wood science (biology, chemistry, wood physics and mechanics, mechanical and chemical processing etc.) Authors are responsible for the fact that the paper has not been published before and it is not under consideration for publication elsewhere.

\section{EDITORS:}

Štefan ŠTELLER, Slovak Forest Products Research Institute, Dúbravská cesta 14, SK-841 04 Bratislava, Slovak Republic.

Monika STANKOVSKÁ, Slovak Forest Products Research Institute, Dúbravská cesta 14, SK-841 04 Bratislava, Slovak Republic.

\section{ASSOCIATE EDITOR:}

Vladimír IHNÁT, Slovak Forests Products Research Institute, Dúbravská cesta 14, SK-841 04 Bratislava, Slovak Republic

\section{EDITORIAL BOARD:}

Ingo BURGERT, ETH Zürich, Institute for Building Materials, HIF E 23.2, Stefano-Franscini-Platz 3, 8093 Zürich, CH-Switzerland

Ignacio J. DIAZ-MAROTO, University of Santiago de Compostela, High School Polytechnic, University Campus s/n, 27002 Lugo, Spain

Miroslav GAŠPARÍK, Czech University of Life Science in Prague, Kamýcká 1176, CZ-165 21 Praha 6 Suchdol, Czech Republic

Vladimŕ GRYC, Mendel University in Brno, Zemedelska 3, CZ-613 00 Brno, Czech Republic

Miha HUMAR, University of Ljubljana, Jamnikarjeva 101, SI-1001 Ljubljana, Slovenia

Jan KANÓCZ, Technical University of Košice, Letná 9, 04200 Košice

Bohuš KASAL, Fraunhofer Institute for Wood Research, Wilhelm-Klauditz-Institut WKI, Bienroder Weg 54 E, D-38108 Braunschweig, Germany

Marián KUČERA, Faculty of Technology of Technical University in Zvolen, Študentská 26, 96053 Zvolen, Slovak Republic

Jozef KÚDELA, Faculty of Wood Sciences and Technology of Technical University in Zvolen, Masarykova 24, 96053 Zvolen, Slovak Republic

Jozef MARTINKA, Slovak University of Technology in Bratislava, Faculty of Materials Science and Technology in Trnava, Jána Bottu č. 2781/25, 91724 Trnava, Slovak Republic

Bartłomiej MAZELA, Poznań University of Life Sciences, ul. Wojska Polskiego 28, PL-60-637 Poznań, Poland Holger MILITZ, University of Göttingen, Büsgenweg 4, D-37077, Göttingen, Germany

Róbert NÉMETH, University of Sopron, Bajcsy Zs. u. 4, H-9400 Sopron, Hungary

Roman RÉH, Technical University in Zvolen, Masarykova 24, SK-960 53 Zvolen, Slovak Republic

Ján SEDLIAČIK, Faculty of Wood Sciences and Technology of Technical University in Zvolen, Masarykova 24, 96053 Zvolen, Slovak Republic

Alfred TEISCHINGER, Boku-University of Natural Resources and Life Sciences, Institute for Wood Technology and Renewable Materials, Konrad Lorenz Strasse 24, 3430 Tulln, Austria

\section{EDITORIAL OFFICE}

Slovenský drevársky výskumný ústav/ Slovak Forest Products Research Institute

Dúbravská cesta 14, SK-841 04, Bratislava, Slovak Republic

Phone: 0911728622 E-mail: woodresearch@vupc.sk, WEB: www.woodresearch.sk

\section{SUBSCRIPTION INFORMATION:}

Wood Research is published six times a year. Subscription rate 150 EUR (including mailing expenses).Subscription order should be sent to Slovak Forest Products Research Institute, Dúbravská cesta 14, SK-841 04 Bratislava, Slovak Republic

(C) 2021 by SDVÚ Bratislava, Slovak Republic

All rights reserved. By submitting a manuscript, the authors agree that the copyright for their article is transferred to their publisher if and when the article is accepted for publication. The copyright covers the exclusive rights to reproduce and distribute the article, including reprints, photographic reproductions, microform or any other reproductions of similar nature and translations. No part of this publication may be reproduced, stored in retrieval system or transmitted in any form or by any means, photocopying, electronic, recording, etc. without the prior written permission of the publisher as mentioned in Slovak Copyright Law No 383/1997.

Issued: February 2021

IČO 31380051

Printed by Pulp and Paper Research Institute, Dúbravská cesta 14, Bratislava, e-mail: sekretariat@vupc.sk 


\section{WOOD RESEARCH \\ Volume 66, Number 2, 2021}

\section{CONTENTS}

1. FAUSTINO RUIZ-AQUINO, ROSSY FERIA-REYES, JOSÉ GUADALUPE RUTIAGA-QUIÑONES, WENCESLAO SANTIAGO-GARCÍA, MARIO ERNESTO SUÁREZ-MOTA, HÉCTOR HUGO ESQUIVELREYES: Development and validation of an analytical method for condensed tannin extracts obtained from

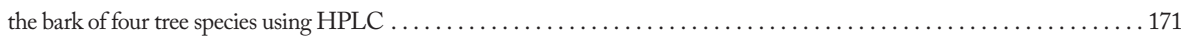

2. QIANG MA, ZHAO LIU, HENGLIN XIAO, ZHI CHEN: Tensile properties of surface modified bamboo slices coated with epoxy resin considering the corrosion of acid and alkali environment $\ldots \ldots \ldots \ldots \ldots \ldots \ldots \ldots \ldots$

3. ANTAL KÁNNÁR, CSILLA CSIHA: Comparative analysis of static and dynamic MoE of pannónia poplar timber

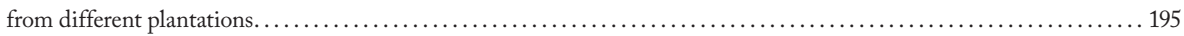

4. DONATA KRUTUL, ANDRZEJ RADOMSKI, ANDRZEJ ANTCZAK, MICHAŁ DROŻDŻEK, TERESA KŁOSIŃSKA, DOMINIKA SZADKOWSKA, JANUSZ ZAWADZKI: Influence of the environmental pollution on the distribution and polymerization degree of cellulose in bark and wood from scots pine (Pinus Sylvestris L.) stem 203

5. ZEYU ZHANG, BINGRU SHAO, FAPENG WANG, JIUYIN PANG, LING SU: Preparation The Rose-like

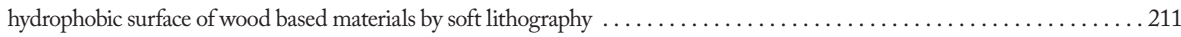

6. VLADIMÍR KUŇA, JOZEF BALBERČÁK, ŠTEFAN BOHÁČEK, VLADIMÍR IHNÁT: Elimination

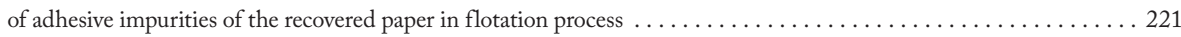

7. SŁAWOMIR KRZOSEK, MAREK GRZEŚKIEWICZ, IZABELA BURAWSKA-KUPNIEWSKA, PIOTR MANKKOWSKI: Mechanical properties of polish-grown Pinus Sylvestris L. structural sawn timber

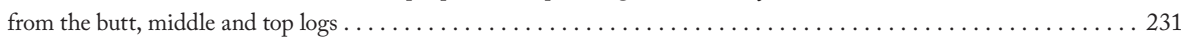

8. EMÍLIA ORÉMUSOVÁ, EVA VÝBOHOVÁ: Changes in gross calorific value of thermally treated scots pine (Pinus Sylvestris L.) and sessile oak (Quercus Petraea L.) wood and their explanation using ftir spectroscopy. . . . 243

9. CHUNYAN LI, XINJIE ZHOU, CANGHAO YANG, HUI LI, LILI YU, BENHUA FEI: Effects of different

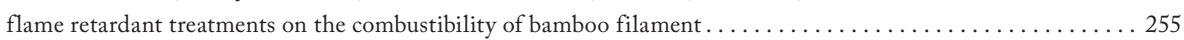

10. VINICIUS BORGES DE MOURA AQUINO, MARCUS VINICIUS PEREIRA DE FREITAS, CLAUDIA QUEIROZ DE VASCONCELOS, JOÃO PAULO BOFF ALMEIDA, FELIPE NASCIMENTO ARROYO, EDSON FERNANDO CASTANHEIRA RODRIGUES, ANDRÉ LUIS CHRISTOFORO, DIEGO HENRIQUE DE ALMEIDA, SERGIO AUGUSTO MELLO SILVA, DIOGO APARECIDO LOPES SILVA, ROBERTO VASCONCELOS PINHEIRO, FRANCISCO ANTONIO ROCCO LAHR: Physical and mechanical characterization of Planchonella Pachycarpa wood species for use in structural purpose ...........267

11. JIALIN ZHANG, HUI XIAO, YUZHU CHEN, JINQIU QI, JIULONG XIE, XINGYAN HUANG, YONGZE JIANG: Porosity and pore size distribution of recent and ancient buried Phoebe Zhennan wood

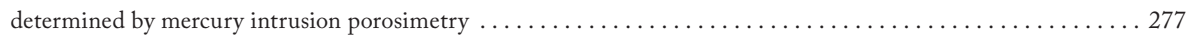

12. MATSHIDISO MAKHALEMA, PERCY HLANGOTHI, SETUMO VICTOR MOTLOUNG, LEHLOHONOLO FORTUNE KOAO, TSHWAFO ELIAS MOTAUNG: Influence of kraft lignin

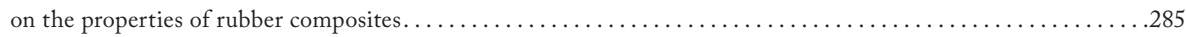

13. YAN YANG, HE SUN, SHUANG YANG, AIFENG WANG, RUI ZHAO, WEI WANG, YIMING HE, BIN LI, BINXIN ZHANG, QIAN WU: Internal cause analysis of damage of wooden components in danxia

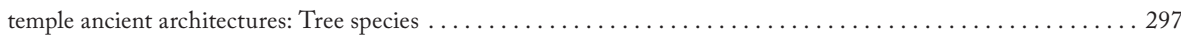

14. ABDURRAHMAN KARAMAN, MEHMET NURI YILDIRIM, ONDER TOR: Bending characteristics of laminated wood composites constructed with black pine wood and aramid fiber reinforced fabric ........ 309

15. TIANXING ZHANG, WENGANG HU: Numerical study on effects of tenon sizes on withdrawal load capacity

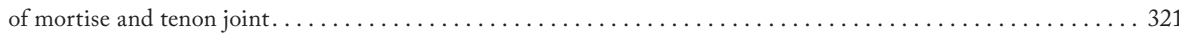

